\title{
Challenges of Rural Industrialization in Edo State
}

\author{
Komolafe, M. O. ${ }^{1, *}$, Oladokun, T. T. ${ }^{2}$ and Iruobe, P. O. ${ }^{1}$ \\ ${ }^{1}$ Department of Estate Management, University of Benin, Benin City, Nigeria \\ ${ }^{2}$ Department of Estate Management, Obafemi Awolowo University, Ile Ife, Nigeria \\ Corresponding Author: *markson.komolafe@uniben.edu
}

\begin{abstract}
Rural industrialization has been identified a potent ingredient for sustainable nation building. This is particularly relevant in Nigeria, given its high unemployment rate and prevailing crisis in its oil sector. This study examines industrialization in a Nigerian rural area, Ebelle community of Edo state. It specifically looks into the existing extent of involvement in industrial activities, the viability of the industrial activities, the challenges and the improvements needed. This is with a view to proffering recommendations on viable approach to revitalizing rural industrialization in Nigeria. It sampled 97 industrialists purposively selected in the study area. The data collected was analyzed using frequency counts and mean values. It is revealed from the study that agricultural activities are more predominant in the study area and it is perceived as most viable by the respondents. However, like in most other industrial activities in the area, inadequate capital, use of primitive methods, and low support on industrial activities has inhibited optimum performance in the agricultural sector. Provision of creditfacilities, government policies that support consumption of local goods and supply of equipment at subsidized process were adjudged the immediate need to improve on the status quo. The study concluded that ample opportunities abound in rural industrialization in Nigeria, provided that tackling the challenges are given utmost priority.
\end{abstract}

Keywords: Rural development, Sustainable development, Rural industrialization, Entrepreneurship, Economic Development.

\subsection{Introduction}

Rural areas have severally been identified as the lifeline of a sustainable national development, especially in the developing economies. According to Lavanya, Hemalatha \& Indumathi (2014), the rural regions of developing economies serve as the stronghold for wealth creation. This is basically because a considerable proportion of primary production activities which form the basis of many other economic activities stem from this segment, for most countries. Hence, rural development has a pivotal role to play in sustainable national development.

Realization of a successful rural development has been linked to industrialization and entrepreneurship in literature (Foster and Rosenzweig, 2004; Saxena, 2012; Patel and Chavda, 2013). Industrialization is being regarded as a strategic development intervention that could accelerate rural development. It stands as a vehicle to improve the quality of life for individuals, families and communities and to sustain a healthy economy and environment (Naudé, 2008). Also, studies (Sundar and Srinivasan, 2009; Sharma, Chaudhary, Bala and Chauhan, 2013) have proved that industrial expansion in the rural areas reduces rural poverty and leads to sustainable livelihoods of villagers which impacts on sustainable national development. Rural industrialization therefore is a dynamic and quintessential concept, and the developmental index of an entire nation. Success with rural industrialization is a yardstick for measuring the wellbeing of an economy.

Rural industrialization as being mentioned before now is generally defined as entrepreneurship emerging at village level which can take place in a variety of fields of endeavour such as business, industry, agriculture, and acts as a potent factor for aggregating economic development (Das, 2014). In other words, establishing industrial and business units in the rural areas in a manner that spurs economic 
growth for both the rural population in question as well as the urban centres it supplies raw materials is what is referred to as rural industrialization. In most cases this term is interchangeably used with rural entrepreneurship. It is a strategy that reduces rural poverty using industrial development from the perspective of rural economy and national economy (Li and Artz, 2009; Muhammad et al., 2014). The revitalizing of the rural economy can be achieved by establishing entrepreneurial ventures in rural areas.

One of the major reasons for rural developmental initiatives relates to the egalitarian policy of the federal government which has sought to achieve a balance in the development of the different sectors of the economy and the various geographical areas of the country. According to Muoghalu (1992), rural development has also attracted more attention due to the growing emphasis on self-reliance, especially in the face of dwindling foreign exchange receipts to service the import sector. This has acquired increased political content as independence means nothing if we have to depend on external sources to sustain the nation in basic food items and industrial raw materials. There is the compelling need to integrate the rural areas of the country into the mainstream of national development politically, socially and economically and for this mobilization, rural industrialization is a potent factor.

The need for rural industrialization, particularly in Nigeria is spurred by the unprecedented decline in industrial, manufacturing and agriculture sector. Dunlop, for instance has relocated to Ghana as well as other industries that have not been able to cope with the decline in power supply and infrastructural base. Nigeria contends with the twin problem of unemployment and poverty and the attendant social problems magnified by the recent insecurity in some parts of the country (National Union of Textile, Garment and Tailoring Workers of Nigeria, 2011). Poverty level remains very high as over 100 million Nigerians are reputed to live below the poverty line (Nwabughiogu, 2016). These are obnoxious, given Nigeria's endowment with vast human and material resources. Nigeria must therefore compliment growth with employment creation. As at 2010, manufacturing contribution to GDP in Nigeria stood at 4.1 per cent while in other middle income countries like India, Singapore and Indonesia, Manufacturing's share of GDP is as high as between 30 and 40 per cent. In China, manufacturing share of GDP is as high as 80 per cent. This figure represents an accelerated decline on the former figures of 15.2 percent contribution in 1982, 8 percent in 1990 and 4.13 percent in 2008; the figure is still falling with massive closure of factories since 2009. Nigeria spent about 8 billion dollars on food importation in 2010 (National Union of Textile, Garment and Tailoring Workers of Nigeria, 2011). This is unacceptable given our vast agricultural resources and potentials. Exploring alternative means of income generation is therefore wise for Nigeria.

The real path to mass job creation and sustainable development is through industrial development. Nigeria must focus on industrial development to propel growth in the agro-allied sector. In order to achieve this, there is need to harness the untapped potentials inherent in industrializing the rural communities. This would help the country resolve existing protracted unemployment and poverty crisis. It will further aid the country in achieving self-reliance through usage of high content of local raw materials in all sectors of the economy.

In order to attain success in the industrialization of rural areas, there is need to examine the series of factors that will likely constitute bottlenecks to its implementation. Banerjee (2011) identified some of these bottlenecks to be government policies (licensing, taxes and tariff), management (in many small firms same individual is responsible for production and management), finance information (lack of information on prices, technology etc.), technology and marketing. Figueroa (1999) points out that rural-urban migration is a major factor affecting rural industrialization as it leads to social exclusion having economic, cultural and political elements which leads to economic exclusion from labour participation and from credit and insurance markets, for the rural people. It is however not all about migration that hinders rural industrialization. In Desai (2007), Govindappa and Geetha (2011), Mushuku and Takuva (2013), Ibiloye (2013) and Lavanya, Hemalatha \& Indumathi (2014), the challenges identified, especially in developing economies include poor infrastructural facilities, finance, lack of skilled labor, problem of standardization, problem of storage and warehousing. 
Empirical studies on the challenges of rural industrialization is sparse in literature; where there are such, they have been based more on case studies (e.g. Li and Artz, 2009; Govindappa and Geetha, 2011). In Nigeria particularly, most existing related studies were carried out on non-rural areas (e.g. Ogaboh and Odu, 2013; Ibiloye, 2013 and Muhammad et al., 2014). There is need for empirical studies on rural industrialization in Nigeria as this will help in solving much of the challenges on sustainable national development in Nigeria. It will help in envisaging likely problems on industrializing the rural areas and aid in projecting planning activities that will encapsulate solutions to these challenges.

Edo state is one of the states that contribute significantly to GDP in Nigeria. The state currently has the fifth highest internally generated revenue in Nigeria, relative to other states in the country (Vanguard, 2016) and is currently Nigeria's second largest producer of rubber and oil palm (World Bank, 2015). Agriculture is the mainstay of the Edo economy and a large proportion of the state citizens depend on agricultural activities for their income. Included among the crops cultivated in the state are oil palm, rubber, cassava, rice, plantain, yam, sweet potatoes, sugar cane, cashew, groundnuts, tomatoes, cotton, and tobacco. A number of agro-processing businesses in the oil palm and rubber processing industry like Okomu Oil Palm Plc and Presco Nigeria Plc and several agricultural research institutes such as the Nigerian Institute for Oil palm Research (NIFOR) and the Rubber Research Institute of Nigeria (RRIN) are located in the state (World Bank, 2015). Based on its abundant land and water resources, much of which lies in the rural areas, Edo has a great potential to expand industrialization in its rural sector and thus improve livelihoods in the state. However, as it applies in most other states in Nigeria, the deplorable state of the rural life and resultant migration to urban areas create doubts on the possibility of achieving this since the seat of primary production activities lies in the rural areas. This study therefore examines the availability and prevalence of the challenges identified in literature in Edo state, Nigeria, being typical of a Nigerian region with a rich mix of both rural and urban areas and given the potential contribution that can be made in the Nigerian industrial sector if Edo rural industrialization is improved upon.

\subsection{Materials and Methods}

For the purpose of this study, Ebelle community of Igueben Local Government Area in Edo state was selected for sampling. The choice of this is informed by its long history of predominance of agriculture and significant enlistment into the cottage industries with significant entrepreneurial activities since most of the population comprise of those who have never worked for the government (formal employment) before but have relied on personal savings and family member's philanthropic gestures to sustain their economic activities. Thus, Ebelle is a typical enclave requiring an industrial transformation especially when we juxtapose the enormous natural agrarian resources with the dearth in processing skills there. It is also not clear whether a community like Ebelle has embraced sufficiently modern farming methods nor can be adduced to have injected modern machinery into farming operation. Also, within the fabrication industry, it is not clear if Ebelle has sufficiently embraced the ideals of mass production techniques and subsequent utilization of non-crude machinery at the primary level (of production) or at the secondary level (of processing) in the area.

Geographically, Ebelle community used to be part of Esan central of Edo state but now part of Igueben LGA of Edo State, Nigeria. Its geographical coordinates are $6^{\circ} 30^{\prime} 0^{\prime \prime}$ North and $6^{\circ} 13^{\prime} 0$ " East. Ebelle is surrounded by other Esan communities such as Ekpon and Ewossa in the South, Amahor in the West, Ogwa in parallel with Ebelle in the North West, Idumodin in the South West, Ewohimi in the South East, and Okalo in parallel with Ebelle in the North East, Igueben in the North East, Ugbegun Nebudin in the North-North West. The villages or quarters that make up Ebelle are Eguare (The seat of His Royal Highness, Aikpaojie I, the Enogie of Ebelle), Ologhe, Okuta, Idumowu and Okpujie.

The economic mainstay of Ebelle include agriculture, commerce, cottage industry (cloth weaving, basket making, etc.), furniture making, wood, etc. In addition, Ebelle is also reputed for palm wine tapping and oil palm production. Ebelle is one of the major traditional towns in Esan, linking to the Benin kingdom (otherwise known as the Binis) like most other Esan communities that are involved in 
the cottage industry. The population of Ebelle appears to be controversial or unknown; however Igueben Local government of which Ebelle is a major constituent part has a population of 69639 according to 2006 population census.

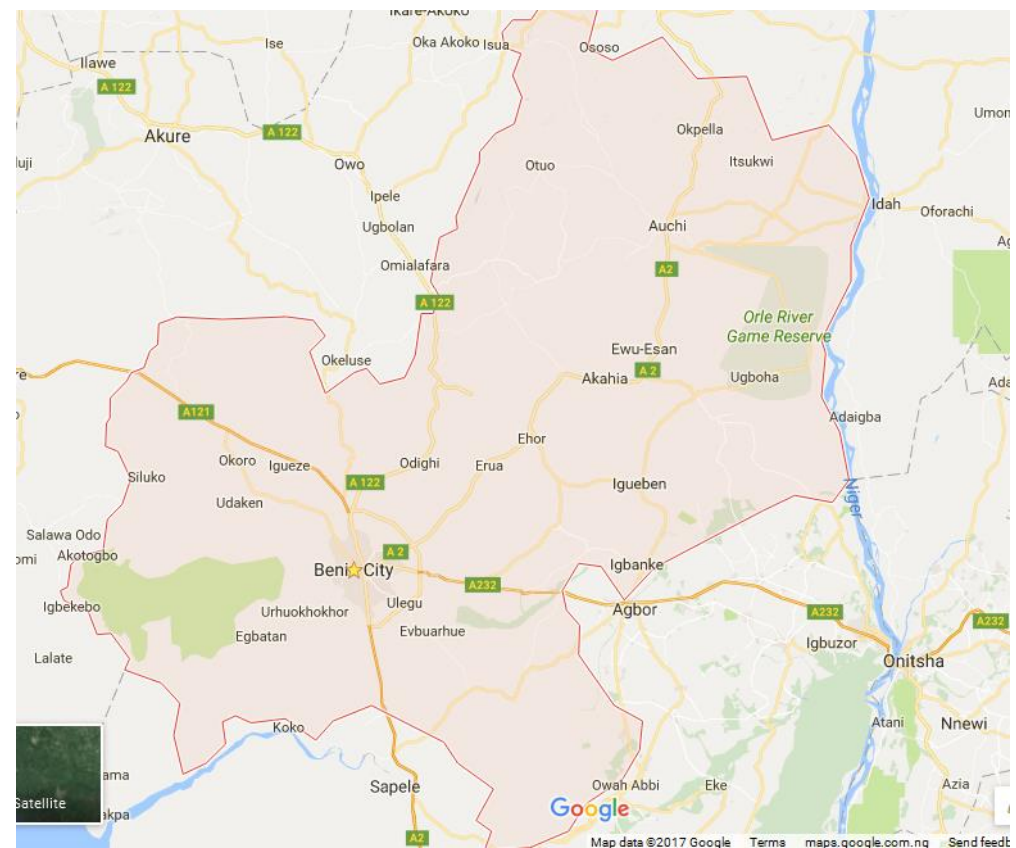

Figure 1: Map of Edo State Showing Igueben Local Government (from Google Map)

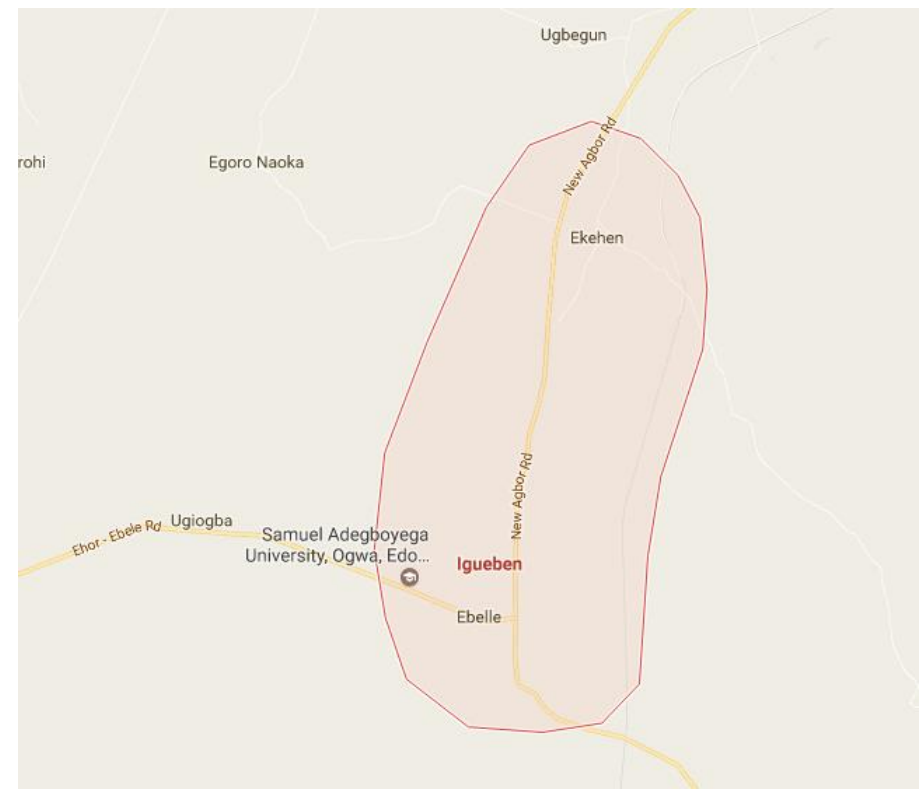

Figure 2: Map of Igueben Local Government Showing Ebelle Community (from Google Map) 


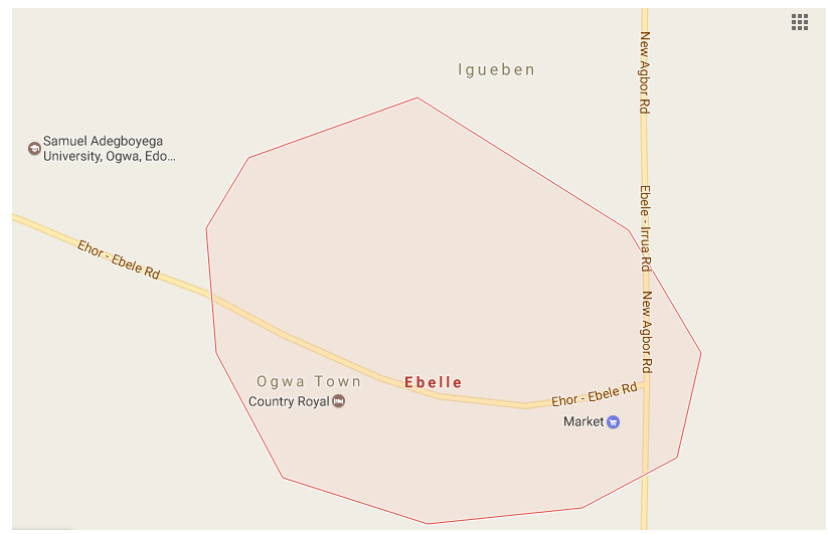

Figure 3: Map of Ebelle Community in Igueben Local Government (from Google Map)

Ebelle as a local community has relied on local processing of its agricultural products for decades. Thus, from production to processing to distribution, the economy still relies on manual inputs and implements not sufficient to transform the economic base from subsistence to commercial. With support, Ebelle stands the chance of an industrial revolution in which palm wine, palm oil, fruits and tubers processing can engender a boost in economic activities as well as business or entrepreneurial transformation. Its vast arable land suitable for agriculture, industrial and agricultural production is a viable instrument of economic turnaround for the people of Ebelle. This initiative is very likely to spread to the surrounding communities and eventually rub on its surroundings and neighbourhood communities. This has the capacity not only to generate employment but increase the standard of living of the rural people. The consequence on the growth of the National economy are ample. Apart from reducing importation due to self-sustenance, it also has the potential to reduce rural-urban migration that has affected the community in the last decade.

The study sampled local industrialists from the five communities that make up Ebelle rural community. Twenty five respondents were selected purposively from each of the five communities, thus a total of 125 questionnaires were distributed, out of which 97 were retrieved. Purposive sampling was considered appropriate given the need to capture the various industrial activities being practiced in their varying scales across the geographical locations in the area. Selection was therefore done to cover diverse nature of industrial activities, size of business outlet and geographical locations in the area. The International Standard Industrial Classification of All Economic Activities, Rev. 4 contains 21 classifications of industrial activities; however, pilot study reveals that only eight out of the 21 classifications were predominant in Ebelle community. These are: Agriculture, forestry and fishing, Mining and quarrying, Manufacturing, Construction, Wholesale and retail trade, Repair of motor vehicles and motorcycles; Transportation and storage, Accommodation and food service activities and Human health and social work activities. Selection of respondents were therefore carefully done to cover the eight categories according to proportion of predominance.

Information contained in the questionnaire include the respondents' personal socio economic characteristics, extent of involvement in existing industrial activities in the area, perceived extent of viability of existing industrial activities; challenges on the industrial activities and the perceived solutions to the identified challenges.

The data was analysed using frequency distributions and mean rating. Frequency counts were used in analysing information related to the respondents' personal characteristics while mean rating was used in analysing other information apart from this.

In order to arrive at the mean values, the respondents were asked to rate, on a five Likert scale the extent of importance or severity (as applicable) of the parameters included in each category of data, 5 representing the highest scale and 1, the least. The resultant mean values for each of the parameters were calculated by multiplying the total frequency of response on each scale with the weight attached. The resultant figures gotten from each scale were added up and divided by the total response on each of the parameters. This is further presented in equation 1 below. 
Mean value $=\frac{\sum_{1}^{5} R \times W}{T}$

Where $\mathrm{R}=$ total number of responses on a particular scale on each parameter

$\mathrm{W}=$ Weight attached to each scale (ranging from 1 to 5 )

$\mathrm{T}=$ Total number of responses on all scales for each parameter

The section that follows presents the result of the analysis in details.

\subsection{Results and Discussion}

The result is sectionalised into two major parts: personal characteristics of the respondents and information on the nature of and challenges on industrial activities in the study area. The personal characteristics of the respondents were sought in order to determine the extent of reliability of the information obtained and draw further inferences on other results, while the second section dwelt more on the subject matter of the research.

\subsection{Personal Characteristics of the Respondents}

From Table 1 below, it can be observed that a greater percentage of the respondents are between ages 40 and 49, married, and have spent at least 25 years in the locality; also the greater proportion only possess primary school education. Given this result, information gotten from the respondents are expected to be more reliable. Also, the low level of education of most respondents is typical of rural dwellers, especially in Africa; information supplied therefore could be projected to other rural areas with similar characteristics with the study area.

Table 1: Personal Characteristics of the Respondents

\begin{tabular}{|lll|}
\hline Age category & Frequency & Percentage \\
$30-39$ & 9 & 9.3 \\
$40-49$ & 49 & 50.5 \\
$50-59$ & 24 & 24.7 \\
$60-69$ & 11 & 11.3 \\
70 and above & 4 & 4.1 \\
Total & 93 & 100 \\
Marital Status & & \\
Category & Frequency & Percentage \\
Married & 72 & 74.2 \\
Single & 17 & 17.5 \\
Widowed & 8 & 8.2 \\
Total & 97 & 100 \\
& & \\
Number of Years Spent in the Locality & Frequency & \\
Category & 2 & Percentage \\
6-10 years & 4 & 2.1 \\
11-15 years & 27 & 4.1 \\
16-20 years & 64 & 27.8 \\
above 25 years & 97 & 66.0 \\
Total & & 100 \\
& & \\
Level of Education & Frequency & \\
Category & 4 & Percentage \\
No formal education & 38 & 4.1 \\
Primary school & 22 & 39.2 \\
Junior secondary & 19 & 22.7 \\
Senior secondary & 4 & 19.6 \\
Adult literacy & 10 & 4.1 \\
B.Sc./HND & 97 & 10.3 \\
Total & & 100 \\
\hline
\end{tabular}




\subsection{Evaluation of Industrial Activities in the Study Area}

In order to provide pertinent information for further analysis, the respondents were asked to indicate the extent to which the existing industrial activities in the study area were being carried out.

Table 2 below summarises the responses, after rating the relative extent on a five likert scale. i.e. "Very much involved" (5) to "Not at all involved" (1). From the table, it is apparent that agriculture, forestry and fishing; wholesale and retail trade; repair of motor vehicles and motorcycles; and accommodation and food service activities are the three predominant industrial activities in the area (in rank order) while construction, human health and social work activities and mining and quarrying are least participated in. This is not surprising, as the result is in consonance with what obtains in a typical African rural area: predominance of Agriculture. Mining and quarrying, Human health and social work activities and Construction activities were the three least pronounced. Mining is less practised due to low level of prevalence of resources needed to carry it out. Less concentration on health services can be traced to the fact that most rural dwellers in the area are used to local herbs and other primitive ways of tackling their health challenges. It is also observable that most of the least practised industrial activities are capital intensive and cannot easily be practised in small scale.

Table 2: Extent of Involvement in Industrial Activities in the Study Area

\begin{tabular}{|ll|}
\hline Category & Mean Value \\
Agriculture, forestry and fishing & 4.4763 \\
Wholesale and Retail trade; repair of motorcycles and motor vehicles & 4.3564 \\
Manufacturing & 3.8956 \\
Accommodation and Food service activities & 3.7643 \\
Transportation and storage & 3.2131 \\
Construction & 2.8561 \\
Human health and social work activities & 2.2654 \\
Mining and quarrying & 1.7355 \\
\hline
\end{tabular}

\subsection{Existing Extent of Viability of Industrial Activities}

Table 3 below shows the extent of viability of the existing industrial activities in the study area, as perceived by the industrialists surveyed. From the table, it can be observed that Agricultural, forestry and fishing, Wholesale and Retail trade activities, repair of bicycles, motorcycles and motor vehicles and food service activities are the most viable (in rank order) while construction, Human health and social work activities, and mining and quarrying are least viable, from their perception. The result on extent of viability of industrial activities in the study area is consistent with that on the extent of involvement. Thus, the industrial activities adjudged to be more viable are the ones with more participants than the ones considered less viable, in most cases. This indicates that barriers/restrictions on entry into the industrial settings in the area are either less cumbersome or more readily surmountable. A slight deviation from the existing trend is observed on transportation and storage industry and construction industry, as construction activities tend to be more viable than transportation and storage industries, according to the respondents' perception, yet more people were involved in transportation and storage, relative to construction. This disparity can be explained by the extent of skills and technical knowhow involved in the construction process which makes it impracticable to dabble into easily unlike the transportation and storage industry that require less of such expertise. To encourage and develop this area, training of labour is therefore relevant; this will in turn boost its contribution to the economy of the community. 
Table 3: Extent of Viability of Industrial Activities

\begin{tabular}{|ll|}
\hline Category & Mean value \\
Agriculture, forestry and fishing & 4.6143 \\
Accommodation and Food service activities & 3.9237 \\
Wholesale, Retail trade; repair of bicycles, motorcycles and motor & 3.8369 \\
vehicles & \\
Manufacturing & 3.6474 \\
Construction & 3.4248 \\
Transportation and storage & 3.2439 \\
Human health and social work activities & 2.7307 \\
Mining and quarrying & 2.4724 \\
\end{tabular}

\subsection{Challenges on Industrial Activities}

The result on the challenges of industrialisation in the study area is as presented in Table 4 below. From the table, it is observable that unavailability of capital for inputs, inadequate supply of equipment and inadequate supply of fertilizers are the three most pressing challenges of industrialisation in the study area while lack of access to farmland, inadequate land space for operation and problems of waste disposal were least important. Inadequate capital for input in the area could have been the reason why manufacturing is less participated in despite high level of primary production (agriculture) since it is difficult to engage in manufacturing without enough capital base. Many could therefore indulge in agricultural activities which can be practised with less capital at the subsistence level. Also, agricultural productions in the area are still being practised with the use of primitive tools and processes. This is explained by the high weight attached to challenges on equipment, fertilizers supplies and availability and use of improved seed. Empowerment of existing and potential industrialists and the encouragement of farmers through the provision of access to more finance will definitely help to improve on manufacturing activities, and resultantly, compliment agricultural activities, thereby building a more viable rural economy, which should help in the employment of more labour within the local industrial setup, and consequently, reduce the challenges of migration and unplanned city growth.

Glancing through the list, it is observable that most of the pressing challenges are related to Agriculture, which is the most dominant industrial activity in the area. Also, majority of the more pressing challenges are related to upgrading agricultural activities through supply of more efficient machineries, fertilizers and improved seed. From the list of challenges, it is can also be inferred that there is need to spread research and development to the rural areas in order to capture the challenges that are peculiar and specific to the mode of practice of industrial activities. For example, lack of use of improved seed, lack of control of pests and diseases and challenges related to product storage and preservation require inquiry. Also attentions should also be devoted to understanding and developing the types of seed that thrive in their soil, the form of pest/ diseases that attack their products and the nature of goods to be preserved.

Also apparent in the result is that most of the more pressing challenges are related more to the primary and secondary production process whilst most of the challenges that rank low are related more to the accompanying services that make industrialisation thrive. The implication of this is that the core production process requires more attention. Land access for industrial activities is of less challenge in the area and this is typical of rural areas as a result of the relatively low population which lessens pressure on demand for land space. 
Generally, the mean values on all challenges are higher than the average of 2.5. This indicates generally high challenges on industrial activities in the study area. Therefore, a lot of improvement can be made on the existing industrial activities when these challenges are mitigated.

Table 4: Challenges of Industrialisation

\begin{tabular}{|ll|}
\hline Challenges & Mean values \\
Capital for inputs & 4.6289 \\
Inadequate supply of equipment & 4.5876 \\
Inadequate supply of Fertilizer & 4.4845 \\
Lack of use of improved seed & 4.4845 \\
Lack of mechanization & 4.4639 \\
Lack of control of pest and diseases & 4.4330 \\
In adequate knowledge about preservation techniques & 4.0928 \\
Lack of storage facility & 4.0825 \\
Access to medical care & 3.9588 \\
Marketing of produce & 3.8866 \\
Availability of raw materials for production & 3.7526 \\
Transportation of produce & 3.7216 \\
Lack of transportation of farm produce to destinations needed & 3.6804 \\
Lack of control on middlemen & 3.5464 \\
Security & 3.2577 \\
Lack of access to farmland & 3.1546 \\
Land/ space for operation & 3.0206 \\
Waste disposal & 2.8454 \\
\hline
\end{tabular}

\subsection{Need for Improvement on Industrial Activities}

In order to detect the areas where efforts are required more for improvement on the status quo on industrial activities in the study area, the respondents were asked to rate the extent of need for an upgrade on the 8 industrial sectors adopted for the inquiry. Table 5 below presents the result. From the table, it is apparent that Manufacturing, Agriculture, forestry and fishing and transportation and storage are the industrial activities that require attention most (as perceived by the respondents); mining and quarrying, construction, and human health and social work activities being the least three. The result reemphasises the need to energize the manufacturing industry in order to maximise the use of agricultural products being produced in the area. Also, the need to boost agriculture and its supporting services is also apparent in the result. It is clear that if agriculture and processing/manufacturing of agricultural products in the study area are encouraged and improved on, economic activities in the area will grow more rapidly, and resultantly, solve some problems of sustainable nation building.

Table 5: Extent of Improvement Needed on Existing Industrial Activities

\begin{tabular}{|l|l|}
\hline Sector & Mean Values \\
Manufacturing & 4.3846 \\
Agriculture, forestry and fishing & 4.2680 \\
Transportation and storage & 3.8944 \\
Accommodation and food service activities & 3.6583 \\
Wholesale and retail trade; repair of motor vehicles and motorcycles & 3.4124 \\
Mining and quarrying & 3.1356 \\
Construction & 3.1165 \\
Human health and social work activities & 2.7550 \\
\hline
\end{tabular}


The section that follows dwells more on what is required by the participants in industrial activities in order to optimise the industrial sector.

\subsection{Perceptions on How to Improve on Existing Performance on Industrial Activities}

Table 6 below contains the respondents' perceptions on the needs to be met in order to address the challenges on industrialisation in the study area. From the table, it can be observed that provision of credit facilities top the list of what is needed. This is followed by formulation of policies that encourage consumption of local products and supply of equipment at subsidised prices. Most other variables in the list have mean values above 4, indicating the need for them in order to improve on the industrial performance. Access to land and control of price are the least two needs of the communities on industrialisation. The result also stress the need for finance in order to empower the rural community in its industrial sector. This is due to the fact that inadequate finance tops the list on the challenges of industrialisation in the area. The high need for policies on consumption of local products indicates the need for more demand and this might be due to fluctuation in demand or inadequate demand for local industrial products. The low demand can in turn result from low quality of product owing to inadequate finance, equipment supply and technical knowhow for standardisation. This is further explained by the high weight placed on the need for equipment supply, improvement in agricultural activities, training and research and development.

Table 6: Perceived Needs in the Industrial Sector

\begin{tabular}{|l|l|}
\hline Solutions & Mean Values \\
Provision of credit facilities & 4.6495 \\
Government policies that support consumption and use of local & 4.4794 \\
products & 4.4227 \\
Supply of equipment at subsidised prices & 4.3505 \\
Provision of better infrastructure & 4.3178 \\
Improvement on agricultural activities to enable better access to raw & 4.1856 \\
materials & 4.1354 \\
Improation and training & 3.9175 \\
Easier access to land & 2.7649 \\
\hline Market control/ price control & \\
\hline
\end{tabular}

\subsection{Conclusion}

It is apparent from this study that industrial activities in the study area have been hampered by inadequate finance as most of the industrial activities that cannot be easily ventured into without high initial capital were less practised. Other industrial activities being engaged in were operated in low scale. Low finance has limited the rural residents' opportunities to explore many viable industrial activities. Thus, there is need for financial empowerment of rural industrialists. This may be in form of granting long term loans, grants and subsidies. It is also observed from the result that unavailability of technical knowhow has limited the scale of operation on some industrial activities (e.g. construction activities). Focus on encouragement of manpower training could therefore boost industrial activities in the area.

The result also revealed the need for research and development especially to study the peculiarity of rural areas and the challenges they face on industrialization. This will help in devising appropriate strategies to tackling challenges such as lack of use of improved seed, lack of control of pests and diseases and challenges related to product storage and preservation being faced in the study area. 
Given the potential contribution of rural industrialisation to sustainable nation building, it is pertinent to pay intent attention to the challenges inhibiting its success in order to overcome them. From this study, the predominance of agricultural industry is apparent and the industrial processes, generally primitive. This has largely been traced to shortage of capital, which in turn resulted into slow rate of development in other industrial activities. With enormous attempt by the government and other relevant stakeholders to tackle the identified challenges, rural industrialisation can shift many steps higher and the inherent advantages spread into other parts of the country, thus, contributing to sustainable nation building.

\section{References}

Banerjee, G. D (2011). Rural Entrepreneurship Development Programme in India - An Impact Assessment. National Bank for Agriculture and Rural Development (Occasional Paper 57).Retrieved from https://www.nabard.org/.../Rural\%20Entrepreneurship\%20Develop.pdf. [Accessed July 19, 2015]

Das D. (2014) Prospects and Challenges of Rural Entrepreneurship Development in NER-A Study International Journal of Humanities \& Social Science Studies (IJHSSS). 1(3) pp. 178-182

Desai V. (2007). Small Scale Industries and Entrepreneurship. Himalaya Publishing House. Mumbai.

Duarte, N and Diniz, F (2011). The role of firms and entrepreneurship in local development. Romanian journal of regional science. 5 (1) pp. 54-69.

Figueroa, A. (1999). Social exclusion and rural underdevelopment. World Bank Conference on Evaluation and Poverty Reduction. Washington, D.C., June 14-15, 1999.

Foster, A.D. and Rosenzweig M.R. (2004). Agricultural Productivity Growth, Rural Economic Diversity and Economic Reforms: India 1970-2000. Economic Development and Cultural Change 52(3) pp. 509-42.

Geetha and Govindappa (2011). Socio-economic Background and Problems of Entrepreneurs in Industrial Estate: A Case study of Industrial Estate in Davangere, Small Enterprises Development, Management \& Extension Journal. 38(3) pp. 1-41.

Ibiloye, E.O. (2013). The challenges of rural industrialization in Kwara State 1970 - 1985. Merit Research Journal of Art, Social Science and Humanities. 1(3) pp. 028-039

Lavanya, S.M. Hemalatha, S. and Indumathi V.M. Perspectives of Rural Entrepreneurship in India. Journal of management research. Vol. 3 Issue 1, pp. 95-100

Li Y. and Artz G.M., (2009), Migration and Rural Entrepreneurship, Working Paper No. 0907, July, Iowa State University, Ames, Iowa

Muhammad S.A., Adamu M. and Alege S.O. (2014) Industrialization and Sustainable Development in Nigeria. The International Journal of Social Sciences and Humanities Invention. 1(3) pp. 142-154. ISSN: 2349-2031

Muoghalu, L.N. (1992). "Rural Development in Nigeria: A Review of Previous Initiatives" In Rural Development in Nigeria: Dynamics and strategies. Edited by Olisa, M.S.O. and Obiukwu, J.I. Meklinks Publishers, Awka.

Mushuku, A and Takuva, R (2013) Growth Points or Ghost Towns? Post-Independence Experiences of the Industrialisation Process at Nemamwa Growth Points in Zimbabwe. International Journal of Politics and Good Governance. 4(4) pp. 1-27

National Union of Textile, Garment and Tailoring Workers of Nigeria (2011) Re-Industrialization, Growth and Employment: Towards Mass Job Creation and Sustainable Industrial Development in 
Nigeria. Text of press statement by National Union of Textile, Garment and Tailoring Workers of Nigeria in Conjunction with Friedrich Ebert foundation on the Occasion of African industrialization day on Monday 21st November, 2011. Retrieved from http://www.fesnigeria.org/common/pdf/PRESS\%20STATEMENT\%20AFRICA\%20INDUSTRIALIZATION\%20D AY.pdf. [Accessed 16 ${ }^{\text {th }}$ March, 2016].

Naudé, W. (2008) Entrepreneurship in Economic Development. Research Paper, UNU-WIDER, United Nations University (UNU), No. 2008/20, ISBN 978-92-9230-066-1

Nwabughiogu, L. (2016) Over 100m Nigerians living below poverty line - Osinbajo. Vanguard. Retrieved from http://www.vanguardngr.com/2015/08/over-1-million-nigerians-living-below-povertyline-osinbajo/. [Accessed 25 ${ }^{\text {th }}$ May 2016]

Ogaboh, A.M. and Odu, E. (2013). Globalization and the Challenge of Industrialization in Developing Nations: The Nigeria Experience. IOSR Journal of Humanities and Social Science. 12(4). pp. 41-47

Patel B. and Chavda K. (2013). Rural Entrepreneurship in India: Challenge and Problems, International Journal of Advance Research in Computer Science and Management Studies. 1(2) pp. 28-37

Saxena, S. (2012). Problems Faced By Rural Entrepreneurs and Remedies to Solve It. IOSR Journal of Business and Management (IOSRJBM) ISSN: 2278-487X. Volume (1). 23-29

Sharma, M., Chaudhary, V., Bala, R. \& Chauhan, R. (2013). Rural entrepreneurship in developing countries: Challenges, problems and performance appraisal. Global Journal of Management and Business Studies, 3(9), pp. 1035-1040.

Sundar, K \& Srinivasan, T. (2009). Rural Industrialization: Challenges and Proposition. Journal of Social Scencei, 20(1): 23-29

Vanguard (2016, June 27) IGR: 36 states generate N682bn. Vanguard. Retrieved from http://www.vanguardngr.com/2016/06/igr-36-states-generate-n682bn/. [Accessed July 5, 2016$]$

Walker, T.S. J.G. Ryan, 2007. "Village and Household Economies in India 's Semi-Arid Tropics". Johns Hopkins University Press, Baltimore.

World Bank (2015) International Development Association Program Document for a Proposed Development Policy Credit in the Amount of SDR 53.3 Million (US\$75 Million Equivalent) to the Federal Republic of Nigeria for a Edo State Fiscal Improvement and Service Delivery Development Policy Operation. Retrieved from http://documents.worldbank.org/curated/en/880091468098970115/text/949940PGD0P151010Box391 420B00OUO090.txt 